\title{
Total synthesis of structures proposed for quinocitrinines A and B and their analogs. Microwave energy as efficient tool for generating heterocycles
}

\author{
Victoria Machtey, Hugo E. Gottlieb, and Gerardo Byk* \\ Laboratory of Nano-Biotechnology, Department of Chemistry, Bar Ilan University, \\ 52900-Ramat Gan, Israel \\ E-mail:bykger@mail.biu.ac.il
}

\begin{abstract}
A first total synthesis of the structures proposed for quinocitrinines $\mathrm{A}$ and $\mathrm{B}$ has been accomplished by a three steps strategy which also applies for the synthesis of non-natural analogs. In the first step a microwave assisted Friedlander condensation between a substituted oamino-benzaldehyde and a substituted tetramic acid generated intermediate fused tricyclic quinolines which were $\mathrm{N}$-methylated using methyl triflate. The natural compounds were obtained after cleavage of an $\mathrm{O}$-methyl group from the aryl ring using $\mathrm{BBr}_{3}$. All the reactions were affected by epimerization of the $\mathrm{C}-11$ in the lactam ring which converted quinocitrinine $\mathrm{A}$ into quinocitrinine B. In order to diminish epimerization, optimization assays were necessary. Extensive NMR analysis of the synthetic compounds and their lack of biological activity as compared to those of the previously isolated natural products, revealed that the structures of the natural products remain to be elucidated.
\end{abstract}

Keywords: Quinocitrinine, quinolinium, antibacterial, microwave, Penicillium citrinum

\section{Introduction}

Quinocitrinines A and B are natural alkaloid compounds extracted from Penicillium citrinum. ${ }^{1}$ Based on spectral data analysis, structure 1 was proposed ${ }^{2}$ for quinocitrinine A and structure 2 for quinocitrinine B (see Scheme 1).

The effect of quinocitrinines was studied on the respiratory activity of yeasts (Yarrowia lipolytica) and bacteria (Arthrobacter globiformis). ${ }^{3}$ Quinocitrinines A and B showed activation of the respiratory process of these native cells in both types of organisms. ${ }^{2}$ Studies of yeast mitochondria showed that quinocitrinines exert an uncoupled effect on oxidative phosphorylation $^{4}$, which activates the respiration and reduces the respiratory control. Experiments with intact mitochondria and the native cells of the bacteria Arthrobacter 
globiformis revealed that quinocitrinines decrease the membrane electrochemical potential. ${ }^{5-7}$ The uncoupling effect likely constitutes a mechanism of the antibiotic activity of quinocitrinines. ${ }^{2}$ Secondary quinoline metabolites are synthesized by bacteria and microscopic fungi. ${ }^{8}$ Quinocitrinines exhibit a broad range of biological activities. ${ }^{2}$ They have anti-tumor activity and induce antibiotic effects in prokaryotic and eukaryotic organisms. ${ }^{9}$

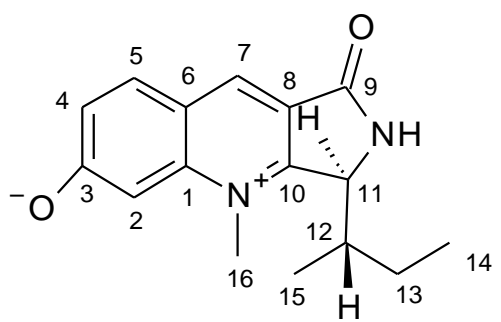

1

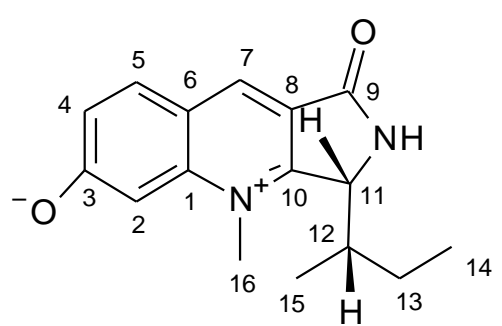

2

Scheme 1. Proposed structures ${ }^{1,2}$ for quinocitrinine A 1 and quinocitrinine B 2. (Arbitrary numbering system according to ${ }^{1}$ for easier comparison of NMR data)

The always growing interest in new antibiotics make from quinocitrinines and their nonnatural analogues, an attractive pole of attention for designing new antibacterial compounds. Here we present the first total synthesis of the structures proposed for quinocitrinines A and B. The proposed general methodology allows the access to a variety of non-natural analogues also included in this study. Structural analyses of the synthetic natural products were compared to those of the isolated natural products obtained in previous studies.

\section{Results and Discussion}

The synthesis is based on a three steps strategy also suitable for the synthesis of non-natural analogues (see Scheme 2). In the first step a microwave assisted Friedlander ${ }^{10}$ condensation between substituted 2-amino-benzaldehydes $\mathbf{3}$ and optically active substituted $S S$-tetramic acids 4 (obtained from the corresponding natural amino acids ${ }^{11}$ ) led to intermediates fused tricyclic quinolines 5a-h which were $\mathrm{N}$-methylated using methyl triflate ${ }^{12}$ at room temperature leading to 6a-h. Finally, compounds 7 were obtained after cleavage of the O-methyl group in $\mathbf{6 h}(\mathrm{R} 1=\mathrm{OMe}$, $\mathrm{R} 2=\mathrm{iBu}$ ) using $\mathrm{BBr}_{3}$ at room temperature ${ }^{13}$ for 7 days or under microwave irradiation for 120 $\min$. 
<smiles>[R7]c1ccc(C=O)c(N)c1</smiles>

3

4

$5 a-h$

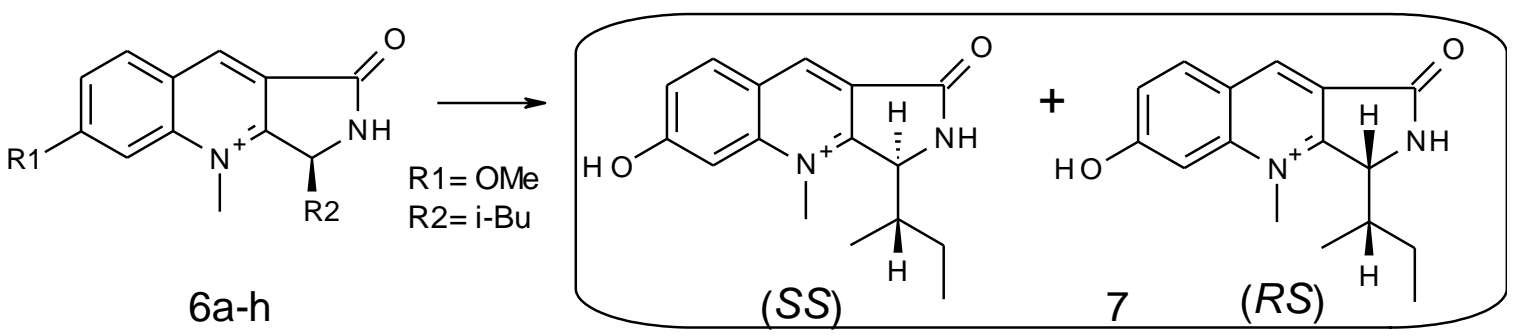

Scheme 2. Synthesis of quinocitrinine analogs starting from tetramic acid derivatives (for $\mathrm{R}^{1}, \mathrm{R}^{2}$ and $\mathrm{R}^{3}$ identity refer to Table 1 ).

Different substitutions at $\mathrm{R}^{1}$ and $\mathrm{R}^{2}$ generated a panel of non-natural analogues (see Table 1).

Table 1. Compounds obtained according to Scheme 2

\begin{tabular}{cccc}
\hline \# & $\mathbf{R}^{\mathbf{1}}$ & $\mathbf{R}^{\mathbf{2}}$ & $\mathbf{R}^{\mathbf{3}}$ \\
\hline $\mathbf{5 a}$ & $\mathrm{H}$ & $\mathrm{H}$ & $\mathrm{H}$ \\
$\mathbf{5 b}$ & $\mathrm{H}$ & sec-bu & $\mathrm{H}$ \\
$\mathbf{5 c}$ & $\mathrm{H}$ & $\mathrm{i}-\mathrm{pr}$ & $\mathrm{H}$ \\
$\mathbf{5 d}$ & $\mathrm{H}$ & $\mathrm{Bn}$ & $\mathrm{H}$ \\
$\mathbf{5 e}$ & $\mathrm{H}$ & $\mathrm{Me}$ & $\mathrm{H}$ \\
$\mathbf{5 f}$ & $\mathrm{H}$ & $\mathrm{i}-\mathrm{bu}$ & $\mathrm{H}$ \\
$\mathbf{5 g}$ & $\mathrm{H}$ & $\mathrm{CH}_{2} \mathrm{COOBn}$ & $\mathrm{H}$ \\
$\mathbf{5 h}$ & $\mathrm{OMe}$ & sec-bu & $\mathrm{Boc}$ \\
$\mathbf{6 a}$ & $\mathrm{H}$ & $\mathrm{H}$ & $\mathrm{H}$ \\
$\mathbf{6 b}$ & $\mathrm{H}$ & sec-bu & $\mathrm{H}$ \\
$\mathbf{6 c}$ & $\mathrm{H}$ & $\mathrm{i}-\mathrm{pr}$ & $\mathrm{H}$ \\
$\mathbf{6 d}$ & $\mathrm{H}$ & $\mathrm{Bn}$ & $\mathrm{H}$ \\
$\mathbf{6 e}$ & $\mathrm{H}$ & $\mathrm{Me}$ & $\mathrm{H}$ \\
$\mathbf{6 f}$ & $\mathrm{H}$ & $\mathrm{i}-\mathrm{bu}$ & $\mathrm{H}$ \\
$\mathbf{6 g}$ & $\mathrm{H}$ & $\mathrm{CH}_{2} \mathrm{COOBn}$ & $\mathrm{H}$ \\
$\mathbf{6 h}$ & $\mathrm{OMe}$ & sec-bu & $\mathrm{H}$ \\
$\mathbf{7}$ & $\mathrm{OH}$ & sec-bu & $\mathrm{H}$ \\
\hline
\end{tabular}


The chirality of intermediates $\mathbf{5 a - h}, \mathbf{6 a - h}$ and products 7 was affected by the conditions of all the applied reactions. Interestingly, the epimerization process in carbon C-11 (see Scheme 1), transforms quinocitrinine $\mathrm{A}(S S)$ into quinocitrinine $\mathrm{B}(R S)$, thus their spectral profiles can be also studied and compared to the natural compounds as mixtures as it will be demonstrated here below.

In order to find optimal reaction conditions, the epimerization process was followed using as model the Friedlander condensation for obtaining the intermediate $5 b\left(R^{1}=H, R^{2}=i-B u\right)$, the Nalkylation of $\mathbf{5 h}$ for obtaining the intermediate $\mathbf{6 h}\left(\mathrm{R}^{1}=\mathrm{OMe}, \mathrm{R}^{2}=\mathrm{i}-\mathrm{Bu}\right)$ and O-demethylation of 6h for obtaining quinocitrinines $7\left(\mathrm{R}^{1}=\mathrm{OH}, \mathrm{R}^{2}=\mathrm{i}-\mathrm{Bu}\right)$. The reason for the selection of these models was the presence of two asymmetric carbons (C-11 and C-12, Scheme 1) that allowed an easy follow-up of epimerization of the $S S$ into the $R S$ isomer using NMR spectroscopy (isomers were not separable by HPLC). Intermediate $\mathbf{5 b}$ is prone to undergo epimerization at the C-11 position due to the vicinity of the quinoline double bond.

The Friedlander condensation was performed under different conditions and the intermediates were analyzed by NMR (see Table 2). Since we noted that Boc protective group is partially cleaved during the reaction, we choose to remove it with trifluoroacetic acid after precipitation of the product mixtures so that NMR spectra could be easily analyzed. It should be pointed out that the crude products were isolated by precipitation from the reaction solvent. Thus, the effective epimerization degree measured by NMR after precipitation might be slightly different from that of the reaction mixtures. Nevertheless, the products were isolated in quantities after precipitation using the same procedure, therefore, the epimerization ratios of the precipitated intermediates are those relevant for the biological studies undertaken using the diastereomeric mixtures.

Table 2. Friedlander condensation conditions and their effect on diastereomeric ratios of intermediate $\mathbf{5 b}$ as observed by NMR of the precipitated mixtures

\begin{tabular}{ccccc}
\hline Exp. & Reaction condition & $S S \%$ & $R S \%$ & $\begin{array}{c}\text { Reaction } \\
\text { time (min) }\end{array}$ \\
\hline $\mathrm{a}$ & $\mathrm{AcOH} / 80^{\circ} \mathrm{C}, \mathrm{MW}$ & 49 & 51 & 10 \\
$\mathrm{~b}$ & $\mathrm{EtOH} / 80^{\circ} \mathrm{C}, \mathrm{MW}$ & 78 & 22 & 10 \\
$\mathrm{c}$ & $\mathrm{CH}_{2} \mathrm{Cl}_{2} / 60^{\circ} \mathrm{C}, \mathrm{MW}$ & 95 & 5 & 60 \\
$\mathrm{~d}$ & $\mathrm{DMF} / 80^{\circ} \mathrm{C}, \mathrm{MW}$ & 96 & 4 & 30 \\
\hline
\end{tabular}

Reactions kinetics were followed by analytical HPLC and the ratio of isomers in the isolated crude was determined by NMR analysis of the precipitated mixtures after total removal of Boc groups (see Figure 1a-d). 

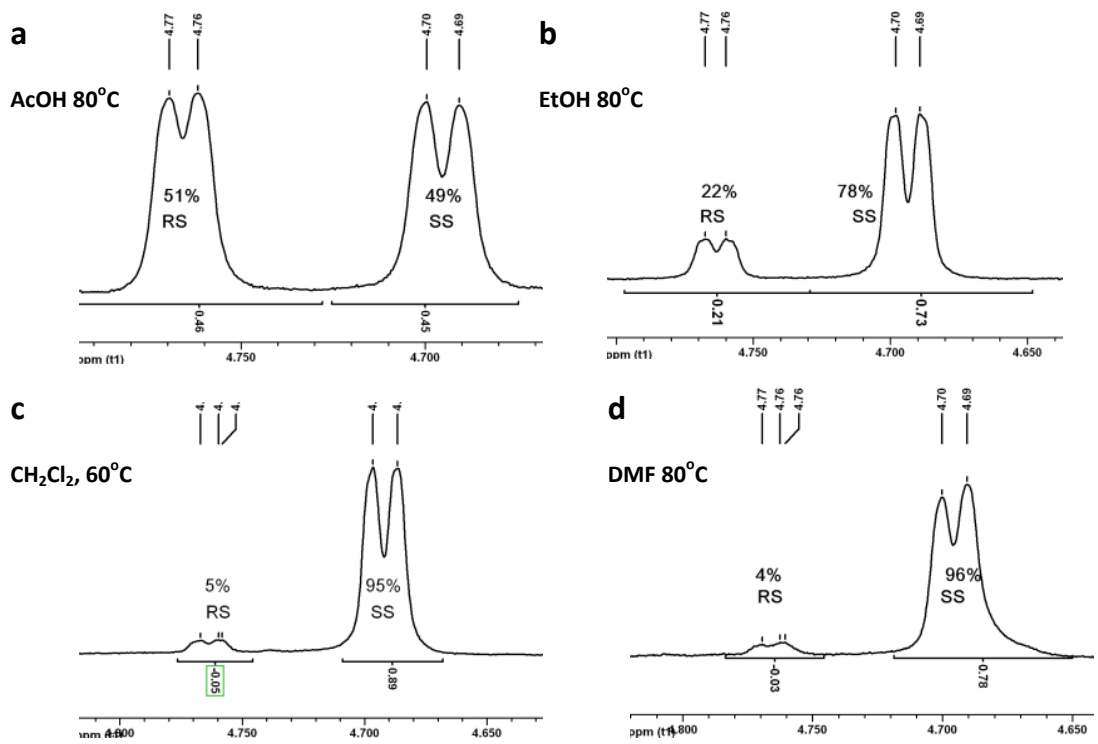

Figure 1. Diastereomers ratios of intermediate compound $\mathbf{5 b}\left(\mathrm{R}^{1}=\mathrm{H}, \mathrm{R}^{2}=\mathrm{i}-\mathrm{Bu}\right)$ obtained by different conditions as measured by ${ }^{1} \mathrm{H}-\mathrm{NMR}$ of the $\mathrm{C}-11$ proton.

Reactions were conducted using microwave energy. Since the starting tetramate (4 in Scheme 2) has a $S S$ configuration we assumed that the $S S$ isomer in $S S / R S$ mixtures will be majoritarian in reactions with low racemization. Thus, the proton on $\mathbf{C}-11$ in $\mathbf{5 b}$ for the $S S$ isomer appears at $4.69 \mathrm{ppm}$, while for the $R S$ isomer appears at $4.76 \mathrm{ppm}$ (see Figure 1). According to the NMR analyses in Figure 1, the acidic solvent acetic acid needed only $10 \mathrm{~min}$ for the total transformation of the starting reagents into the product, however a total epimerization was observed (see Table 2, exp. a and Figure 1a). Protic solvent ethanol at $80^{\circ} \mathrm{C}$ inferred less epimerization as compared to acetic acid under similar reaction conditions (see Table 2, exp. b and Figure 1b). Finally the use of aprotic solvents; either polar or not, resulted in the generation of moderately less epimerized products that needed longer, but reasonable, reaction times of 30 to $60 \mathrm{~min}$. (see Table 2, exp. c-d and Figure 1c-d). Overall, for a lesser epimerization the use of aprotic solvents at temperatures lower than $80^{\circ} \mathrm{C}$ are preferred (4\% of $R S$ isomer was obtained). On the other hand, working at high temperature in protic solvents resulted in a significant epimerization. Yields varied from 30 to $60 \%$. Finally, as expected, Boc protecting groups were substantially cleaved during experiments $a-b$ and partially cleaved in experiments $c-d$.

Since the epimerization was minimal using $\mathrm{DMF} / 80^{\circ} \mathrm{C} / \mathrm{MW}$ we applied these conditions to the synthesis of the quinocitrinine precursor $5 \mathbf{h}\left(\mathrm{R}^{1}=\mathrm{OMe}, \mathrm{R}^{2}=\mathrm{i}-\mathrm{Bu}\right.$ in Figure 2). Strikingly, the product did not precipitate from the reaction solvent and it was necessary to add water and extract it with ethyl acetate. The isolated crude was a mixture of the expected products where $90 \%$ of the Boc groups remained intact. Thus this mixture was purified by silica gel and the Bocprotected product was analyzed by NMR. The ratio of diastereomers $S S: R S$ was $96: 4$, thus the same as the obtained for $\mathbf{5 b}$ under the same conditions (see Figure 2a, note that in starting compound $\mathbf{5 h}$ the NMR signals of the isomers are swapped due to the presence of the Boc group 
which affects the chemical shifts of both isomers, downfield, but more significantly the $S S$ isomer with $5.16 \mathrm{ppm}$ than the $R S$ isomer with $5.10 \mathrm{ppm}$ for the proton on $\mathrm{C}-11)$.

The N-methylation was conducted using the isomers mixture (SS:RS) 96:4 of intermediate $\mathbf{5 h}$ to give $6 \mathrm{~h}(\mathrm{R} 1=\mathrm{OMe}, \mathrm{R} 2=\mathrm{i}-\mathrm{Bu})$. Methylation of the intermediate was performed in dry dichloromethane using methyl triflate under nitrogen at room temperature as previously reported $^{12}$, the Boc group was completely cleaved during the reaction likely due to the presence of the Lewis acid and/or to the strong inductive electron withdrawing effect generated by the presence of the quinolinium cation. A further epimerization of $\mathrm{C}-11$ in intermediate $\mathbf{6 h}$ was observed by NMR (see Figure 2b). Thus, the starting epimeric mixture (SS:RS) 96:4 evolved to $83: 17$ with a yield of $72 \%$. Further optimization was discarded as some epimerization was observed even under mild conditions.

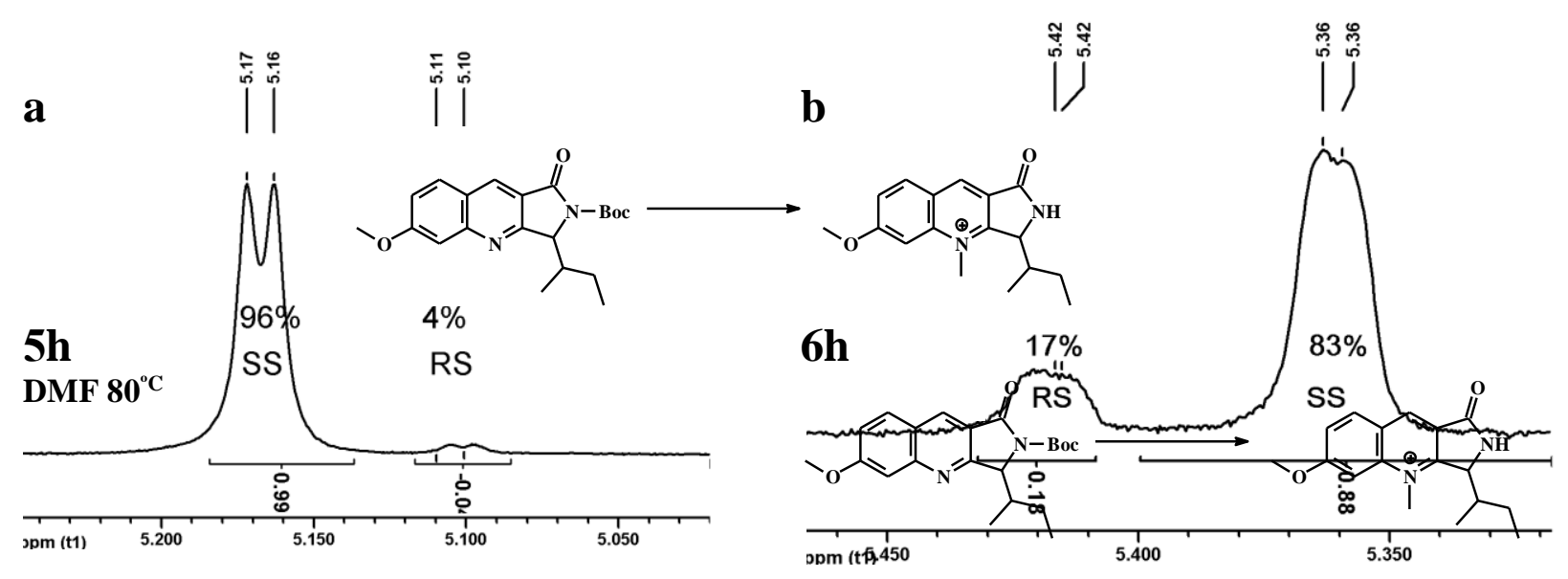

Figure 2. C-11 proton $R S$ to $S S$ isomers ratio obtained by $1 \mathrm{H}-\mathrm{NMR}$ of compound $\mathbf{6 h}$ (right panel) after methylation of $\mathbf{5 h}$ (left panel).

Finally, demethylation of the O-Me group in quinocitrinine precursor $\mathbf{6 h}$, was conducted using the isomers mixture (SS:RS) 83:17. Two different conditions were tested: aqueous $\mathrm{HBr}$ under microwave irradiation at $100^{\circ} \mathrm{C}$ during $90 \mathrm{~min}$, with very poor yield (data not shown) and $\mathrm{BBr}_{3}$ in $\mathrm{CH}_{2} \mathrm{Cl}_{2}$ for 7 days at room temperature as previously reported. The final products 7 were purified by preparative HPLC as mixtures and analyzed by NMR. Results in Figure 3 indicate that the contribution of this step to the epimerization process was rather small with a final isomers $S S: R S$ ratio of $76: 24$ and $40 \%$ yield. 


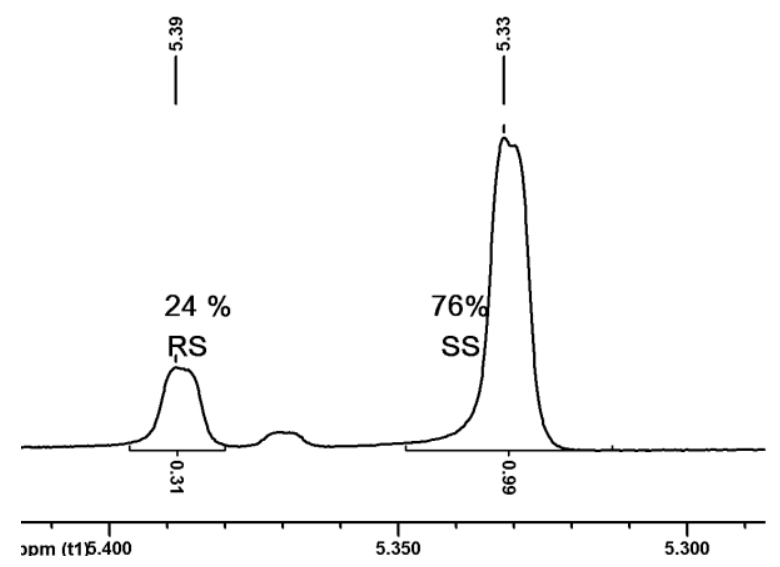

Figure 3. C-11 proton $1 \mathrm{H}-\mathrm{NMR}$ of compound 7 after O-demethylation of $\mathbf{6 h}$ using $\mathrm{BBr}_{3}$ in $\mathrm{CH}_{2} \mathrm{Cl}_{2}$.

Overall, the best conditions for obtaining highly stereoselective products were the use of non protic solvents either methylene chloride or DMF at not more than $80^{\circ} \mathrm{C}$ for the Friedlander condensation, $\mathrm{N}$-methylation using methyl triflate at room temperature and O-demethylation needed the use of $\mathrm{BBr}_{3}$ with no heating for a week.

Except for products $\mathbf{6 a}$ and $\mathbf{6 b}$, the non-natural analogues contain a single asymmetric carbon, thus they were obtained as racemic mixtures. For this reason we preferred to generate quantities of these compounds using the epimerizing conditions to obtain unambiguous ratio of 1:1 for the enantiomer mixtures which allows an easier evaluation of eventual biological activity (see Table 3). Thus, acetic acid was used for the synthesis of intermediates $5 \mathbf{b}$-g so that compounds $\mathbf{6 b}-\mathbf{g}$ were a 1:1 mixture of two enantiomers (two diastereomers for $\mathbf{6 b}$ ).

Table 3. Summary of analyses of synthetic quinocitrinines and analogs

\begin{tabular}{cccccc}
\hline Symbol & $\begin{array}{c}\text { HR-MS } \\
\text { calc. }\end{array}$ & $\begin{array}{c}\text { HRMS } \\
\text { found }\end{array}$ & $\begin{array}{c}\text { HPLC, } \\
\text { Rt, min }\end{array}$ & $\begin{array}{c}\mathrm{N}^{\circ} \\
\text { steps }\end{array}$ & $\begin{array}{c}{ }^{\mathrm{a}} \text { Total } \\
\text { Yield }\end{array}$ \\
\hline 6a & 199.087 & 199.088 & 1.57 & 2 & $73 \%$ \\
6b & 255.149 & 255.149 & 3.24 & 2 & $33 \%$ \\
6c & 241.134 & 241.133 & 3.04 & 2 & $36 \%$ \\
6d & 289.133 & 289.132 & 3.28 & 2 & $59 \%$ \\
6e & 213.102 & 213.102 & 2.58 & 2 & $30 \%$ \\
6f & 255.149 & 255.150 & 3.21 & 2 & $49 \%$ \\
6g & 347.139 & 347.139 & 3.40 & 2 & $26 \%$ \\
6h & 285.160 & 285.150 & 3.38 & 2 & $26 \%$ \\
7 & 271.144 & 271.143 & 3.08 & 3 & $10 \%$ \\
\hline
\end{tabular}

${ }^{[a]}$ Overall yield. 
In order to confirm the proposed structures of the previously isolated quinocitrinines $\mathrm{A}$ and B, the synthetic mixture 7 was analysed by UV, IR, TLC and extensively studied by NMR spectroscopy (see Table 4 for general physical properties). The mixture of choice for NMR studies was composed of a $S S: R S$ ratio of 79:21. $1 \mathrm{D}{ }^{1} \mathrm{H}$ and ${ }^{13} \mathrm{C}$ NMR spectra were recorded, as well as several 2D correlation spectra (COSY, HMQC and HMBC). Pyridine- $\mathrm{d}_{5}$ was used as solvent for these NMR spectra in order to work under the same conditions of the previously reported NMR data. ${ }^{1}$ The chemical shifts of the synthetic analogues were, in many cases, strikingly different from those of the previously reported NMR data of the natural compounds. ${ }^{1}$ Firstly, the spectra of the synthetic quinocitrinines A and B (diastereomers) were found to be different from each other, unlike the literature report where carbons and protons from both isomers were systematically attributed to single signals. In addition, proton chemical shifts differ by $0.3-1.3 \mathrm{ppm}$ from those of the literature report (see Table 5).

Table 4. Physical properties of synthetic 7 and natural quinocitrinines

\begin{tabular}{|c|c|c|c|}
\hline & Synthetic $7 S S+R S$ & Quinocitrinine A & Quinocitrinine B \\
\hline Appearance & yellow solid & & \\
\hline $\operatorname{Mp}\left({ }^{\circ} \mathrm{C}\right)$ & $95-98$ & $142-143$ & $152-153$ \\
\hline Molecular formula & $\mathrm{C}_{16} \mathrm{H}_{19} \mathrm{~N}_{2} \mathrm{O}_{2}$ & $\mathrm{C}_{16} \mathrm{H}_{19} \mathrm{~N}_{2} \mathrm{O}_{2}$ & $\mathrm{C}_{16} \mathrm{H}_{19} \mathrm{~N}_{2} \mathrm{O}_{2}$ \\
\hline HR-MS calc & 271.1441 & & \\
\hline found & 271.143 & 271.1373 & 271.1374 \\
\hline $\begin{array}{l}\text { UV-VIS } \\
\mathrm{MeOH}, \lambda_{\max .}(\mathrm{nm})\end{array}$ & $230,296,315$ & $216,248.256$ & $00,314,328$ \\
\hline $\begin{array}{l}\text { IR film, } \\
v_{\text {max. }}\left(\mathrm{cm}^{-1}\right)\end{array}$ & $\begin{array}{c}3198,3081, \underline{1712}, 1670, \\
1625,1589,1518,1482, \\
1456,1417,1367,1318, \\
1272,1192,1134,1079, \\
949,830,798,719\end{array}$ & $\begin{array}{c}3263, \underline{1689}, 1604,1545 \\
1523,1462,1420\end{array}$ & $\begin{array}{c}3245, \underline{1690}, 1605, \\
1545,1524,1462,1420\end{array}$ \\
\hline \multicolumn{4}{|c|}{ Rf on TLC (silical gel aluminum sheets): } \\
\hline $\begin{array}{l}\text { Solvent 1: } \\
\mathrm{CHCl}_{3}-\mathrm{MeOH}-\mathrm{NH}_{4} \mathrm{OH} \\
(80: 20: 0.2)\end{array}$ & 0.67 and 0.64 & 0.68 & 0.62 \\
\hline $\begin{array}{l}\text { Solvent 2: } \\
\mathrm{CHCl}_{3}-\mathrm{MeOH}-\mathrm{NH}_{4} \mathrm{OH} \\
(90: 10: 1)\end{array}$ & 0.17 & 0.49 & 0.45 \\
\hline $\begin{array}{l}\text { Solvent 3: } \\
\mathrm{CHCl}_{3}-\mathrm{MeOH}-\mathrm{NH}_{4} \mathrm{OH} \\
(90: 10: 0.1)\end{array}$ & 0.28 and 0.24 & 0.14 & 0.12 \\
\hline
\end{tabular}


Moreover, the carbon chemical shifts also differ substantially from the previously reported data (see Table 6); for example in the reported natural quinocitrinines A and B, the C-2 carbon has a unique chemical shift of $116.6 \mathrm{ppm}$; however the chemical shift of the same carbon for both synthetic isomers was $102.78 \mathrm{ppm}$, thus a difference of $13.8 \mathrm{ppm}$ between the natural and synthetic products. Strikingly, the carbon in the same position of another natural product with the same empirical formula, quinolactacin A, shown a similar chemical shift of $117 \mathrm{ppm}$ in DMSO (see Scheme 3). ${ }^{14}$ The C-6 was reported as having a single chemical shift of 129.8 ppm for both natural isomers, however the synthetic compounds disclosed a chemical shift of $123.6 \mathrm{ppm}$. Again quinolactacin A disclosed a chemical shift of $128 \mathrm{ppm}$ in DMSO very close to that of the natural compound. ${ }^{14}$ For C-8 the situation was even more distinct as each synthetic isomer disclosed a slightly different chemical shift of $119.83 \mathrm{ppm}$ and $119.98 \mathrm{ppm}$, both substantially different from a single chemical shift of $111.0 \mathrm{ppm}$ reported for both natural products and very close to the same carbon in quinolactacin A (110,3 ppm in DMSO) ${ }^{14}$ Finally, for the $\mathrm{N}^{+}-\mathrm{Me}$ C16 of the quinolinium group, chemical shifts of 39.22 and $39.17 \mathrm{ppm}$ were obtained for the synthetic products, while 36.8 for the natural compounds also very similar to the chemical shift measured for quinolactacin A (36 ppm in DMSO), that possesses an oxidized uncharged $\mathrm{N}$ methyl quinolinone ring instead of the $\mathrm{N}$-methyl-quinolinium, with the same general formula as the proposed structure of the natural products ${ }^{14}$ (see Table 6).

Table 5. ${ }^{1} \mathrm{H}-\mathrm{NMR}$ Chemical shifts of synthetic as compared to natural ${ }^{1}$ quinocitrinines

\begin{tabular}{cccc}
\hline Position & Synthetic & Synthetic & Natural \\
& $7 S S$ & $7 R S$ & Quinocitrinine A and B \\
\hline 1 & - & - & - \\
2 & $7.97 \mathrm{~s}$ & $8.01 \mathrm{~s}$ & $7.60 \mathrm{~d}, 1.5$ \\
3 & - & - & - \\
4 & $7.57 \mathrm{dd}, 2.1,9$ & $7.56 \mathrm{dd}, 2.1,9$ & $7.38 \mathrm{dd}, 1.5,7.4$ \\
5 & $8.00 \mathrm{~d}, 9$ & $7.99 \mathrm{~d}, 9$ & $8.7 \mathrm{dd}, 7.4,1.0$ \\
6 & - & - & - \\
7 & $8.95 \mathrm{~s}$ & $8.94 \mathrm{~s}$ & $7.60 \mathrm{~d}, 1.0$ \\
8 & - & - & - \\
9 & - & - & - \\
10 & - & - & $4.88 \mathrm{~m}$ \\
11 & $5.40 \mathrm{~d}, 2.1$ & $5.43 \mathrm{~d}, 2.1$ & $2.21 \mathrm{~m}$ \\
12 & $2.5 \mathrm{~m}$ & $2.45 \mathrm{~m}$ & $0.82 \mathrm{~m}, 0.90 \mathrm{~m}$ \\
13 & $0.81 \mathrm{~m}, 1.05 \mathrm{~m}$ & $1.62 \mathrm{~m}, 1.83 \mathrm{~m}$ & $0.49 \mathrm{t}, 7.1$ \\
14 & $0.61 \mathrm{t}, 7.7$ & $1.10 \mathrm{t}, 7.7$ & $1.21 \mathrm{~d}, 6.9$ \\
15 & $1.37 \mathrm{~d}, 7$ & $0.52 \mathrm{~d}, 7$ & $3.60 \mathrm{~s}$ \\
16 & $4.31 \mathrm{~s}$ & $4.29 \mathrm{~s}$ &
\end{tabular}




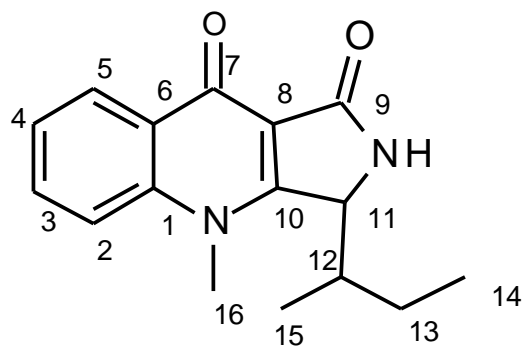

Scheme 3. Structure of quinolactacin A (arbitrary numbering system for easier comparison with the natural quinocitrinines $\mathrm{A}$ and $\mathrm{B}$ and 7).

Table 6. ${ }^{13} \mathrm{C}-\mathrm{NMR}$ Chemical shifts of synthetic as compared to natural ${ }^{1}$ quinocitrinines

\begin{tabular}{cccc}
\hline Position & $\begin{array}{c}\text { Synthetic } \\
7 S S\end{array}$ & $\begin{array}{c}\text { Synthetic } \\
7 R S\end{array}$ & $\begin{array}{c}\text { Natural } \\
\text { Quinocitrinine } \\
\text { A and B }\end{array}$ \\
\hline 1 & 144.93 & 144.99 & $141.1(\mathrm{~s})$ \\
2 & 102.79 & 102.79 & $116.6(\mathrm{~d})$ \\
3 & 175.72 & 175.78 & $172.5(\mathrm{~s})$ \\
4 & 127.25 & 127.25 & $124.8(\mathrm{~d})$ \\
5 & 133.88 & 133.92 & $126.8(\mathrm{~d})$ \\
6 & 123.00 & 123.00 & 129.8 \\
7 & 137.51 & 137.57 & $132.7(\mathrm{~d})$ \\
8 & 120.32 & 120.18 & $111.0(\mathrm{~s})$ \\
9 & 167.01 & 167.19 & $169.9(\mathrm{~s})$ \\
10 & 161.58 & 161.90 & $164.7(\mathrm{~s})$ \\
11 & 62.08 & 59.90 & $60.2(\mathrm{~d})$ \\
12 & 37.15 & 37.15 & $36.7(\mathrm{~d})$ \\
13 & 22.04 & 28.52 & $21.3(\mathrm{t})$ \\
14 & 11.55 & 12.11 & $11.5(\mathrm{q})$ \\
15 & 17.94 & 12.20 & $17.8(\mathrm{q})$ \\
16 & 39.22 & 39.17 & $36.8(\mathrm{q})$ \\
\hline
\end{tabular}

Finally, HMBC (long-range ${ }^{1} \mathrm{H} \mathrm{x}{ }^{13} \mathrm{C}$ ) correlations shown in Table 7 clearly suggest that the synthetic and the reported natural products are different. Since we don't have access to the natural products, it is not possible to perform exhaustive comparative studies in order to clearly establish a structure for the natural products, the only indication we have to date is that the chemical shift of the N-Me group in the natural compounds, strongly suggest that the heterocycle 
contains a quinolinone ring rather than a quinolinium one and that all the chemical shifts of the carbons are strikingly similar to those of another natural compound, quinolactacin $\mathrm{A}^{14}$ with the same general formula. It should be pointed out that although we find a systematic correlation between the chemical shifts of all the carbons and most of the protons of the natural compounds and quinolactacin $\mathrm{A}$, we are not able to establish their current structure since we note that multiplicity in protons $\mathrm{C} 2, \mathrm{C} 4$ and $\mathrm{C} 5$ match the presence of a group different from proton in position C3. Overall, we suggest that the structures previously proposed for natural quinocitrinines A and B must be considered cautiously.

Table 7. 2-/3-bond ${ }^{1} \mathrm{H} \mathrm{x}{ }^{13} \mathrm{C}$ correlations (HMBC) for synthetic (left) as compared to natural ${ }^{1}$ (right) quinocitrinines
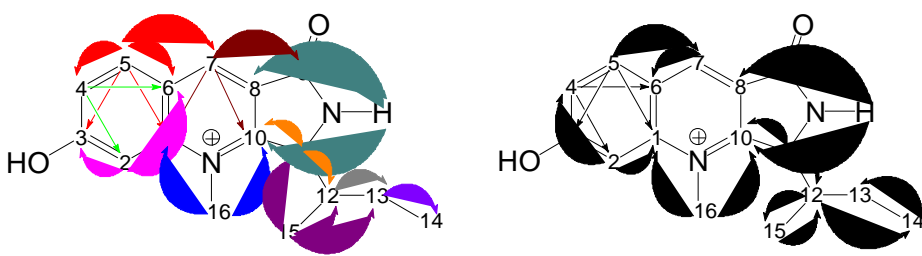

\begin{tabular}{|c|c|c|c|c|}
\hline \multirow[t]{2}{*}{$\begin{array}{l}{ }^{1} \mathrm{H} \\
\text { Position }\end{array}$} & \multicolumn{2}{|l|}{$\begin{array}{l}\text { Synthetic } \\
7 S S+R S\end{array}$} & \multicolumn{2}{|l|}{$\begin{array}{l}\text { Natural } \\
\text { Quinocitrinine }\end{array}$} \\
\hline & ${ }^{2} J_{\mathrm{CH}}$ & ${ }^{3} J_{\mathrm{CH}}$ & ${ }^{2} J_{\mathrm{CH}}$ & ${ }^{3} J_{\mathrm{CH}}$ \\
\hline 1 & - & - & - & - \\
\hline 2 & C- 1,3 & C-4 & C-1 & C-4 \\
\hline 3 & - & - & - & - \\
\hline 4 & - & $C-2,6$ & - & $C-2,6$ \\
\hline 5 & $C-4,6$ & $\mathrm{C}-3,1,7$ & - & C- $3,1,7$ \\
\hline 6 & - & - & - & - \\
\hline 7 & - & $\mathrm{C}-1,9,10$ & C-6 & $C-5$ \\
\hline 8 & - & - & - & - \\
\hline 9 & - & - & - & - \\
\hline 10 & - & - & - & - \\
\hline 11 & C-12, 10 & C- 13,15 & C- 10,12 & - \\
\hline 12 & C- $-13,15$ & - & C- 11,15 & C-14 \\
\hline 13 & C-14, 12 & - & C-14 & - \\
\hline 14 & C-13 & C-12 & C-13 & C-12 \\
\hline 15 & C-12 & C- 11,13 & C-12 & - \\
\hline 16 & - & C- 1,10 & - & C-1, 10 \\
\hline
\end{tabular}

All the compounds, including intermediates were tested for cell viability using XTT viability assay and were also tested as antibacterial by the minimal inhibitory concentrations (MIC) 
assay $^{15}$ in Staphylococcus aureus and Escherichia coli. Synthetic quinocitrinines A and B as well as the non-natural analogues were devoid of activities in both assays up to concentrations of 100 mM. (data not shown). The lack of activity of the synthetic quinocitrinines and derivatives are an additional indication for the lack of correlation between the previously reported active "quinocitrinines" and the compounds synthesized here. Finally, we did not find necessary to further separate the racemic non-natural compounds 6c-g or separate the "synthetic quinocitrinines" $7 \mathbf{h}$ as they were devoid of activity both as anti-bacterial and anti tumoral.

\section{Conclusions}

We have developed a first total synthesis of the proposed structures of quinocitrinines A and B. The synthesis includes three key reactions: a) Friedlander condensation, b) N-methylation and, c) O-demethylation. All the reactions affected the chiral integrity of carbon $\mathrm{C}-11$, thus in order to diminish epimerization, optimization studies were undertaken for finding the best conditions.

The method was applied to the synthesis of other novel non-natural quinocitrinine analogs. Strikingly, exhaustive NMR analysis of the obtained synthetic quinocitrinines revealed a substantial lack of correlation between the chemical shifts and $\mathrm{CH}$ correlations of the synthetic and the natural products. Moreover, XTT viability assays and MIC assays revealed a lack of activity for all the synthesized compounds up to $100 \mathrm{mM}$. Overall, we suggest that the structures proposed for the natural quinocitrinines $\mathrm{A}$ and $\mathrm{B}$ in previous reports should be reconsidered.

\section{Experimental Section}

General. Analytical HPLC was performed on Waters Gradient System equipped with a 717-Plus autosampler, a Waters 600 intelligent pump, and a Waters 996-photodiode array detector; the system was piloted with Millenium software from Waters. Selected wavelengths for chromatograms were 220 and $254 \mathrm{~nm}$. Mobile phases were (A) $\mathrm{H}_{2} \mathrm{O}(0.1 \%$ TFA) and (B) MeCN (0.08\% TFA). Separation condition for analytical analysis was as follows: Column Merck Chromolith Performance RP-18e 100-4.6 nm, gradient $\mathrm{H}_{2} \mathrm{O} / \mathrm{MeCN}$, gradient a [A/B] 1 min [100/0], 1-8 $\mathrm{min}$ [0/100], 8-11 $\mathrm{min}$ [0/100], $11.1 \mathrm{~min}$ [100/0]; flow rate $6 \mathrm{~mL} / \mathrm{min}$. Preparative separation was performed using a Gilson HPLC, Column Vydac RP-18 1 inch with gradient $\mathrm{H}_{2} \mathrm{O} / \mathrm{MeCN} 3 \mathrm{~min}$ [100/0], 3-40 $\mathrm{min}$ [0/100], 40-45 $\mathrm{min}$ [0/100]. Flow rate $30 \mathrm{ml} / \mathrm{min}$. NMR spectra were obtained on Bruker DPX-300 (300.1 and 75.5 M Hz for ${ }^{1} \mathrm{H}$ and ${ }^{13} \mathrm{C}$, respectively) and Avance III -700 (700.5 and $176.1 \mathrm{M} \mathrm{Hz}$ for ${ }^{1} \mathrm{H}$ and ${ }^{13} \mathrm{C}$, respectively) spectrometers. Samples were dissolved in DMSO- $\mathrm{d}_{6}$ or pyridine- $\mathrm{d}_{5}$. Chemical shifts are in ppm relative to TMS internal standard, or the solvent. ${ }^{13} \mathrm{C}-\mathrm{NMR}$ multiplicities were confirmed by the DEPT technique, and several 2D correlation spectra were also taken COSY, HMQC and HMBC. Mass spectra analyses were obtained on a Varian Mat 731 spectrometer $(\mathrm{CI}=$ chemical ionization). 
High resolution MS-MALDI-TOF spectra with an Autoflex TOF/ TOF instrument (Bruker, Germany). 2, 5-Dihydroxybenzoic acid (DHB) was used as a matrix. Microwave irradiations were carried out with a professional microwave "Initiator" from Biotage at pre-fixed temperature. The intensity differed from 0 to $300 \mathrm{~W}$ at frequency of $2.456 \mathrm{G} \mathrm{Hz}$. The tetramic acids were prepared according to a procedure published recently. ${ }^{11}$ 2-aminoanisaldehyde for preparation of $\mathbf{5 h}$ was synthesized according to previous works. ${ }^{16-17}$

Procedure for the synthesis of intermediates (5a-g). $3.25 \mathrm{mmol}$ of Boc-tetramic acid , 2.45 mmol of 2-aminobenzaldehyde 3 and $5 \mathrm{ml} \mathrm{AcOH}$ were poured into a microwave reaction vial. The vial was flushed with nitrogen, sealed and irradiated for $10 \mathrm{~min}$ at $120^{\circ} \mathrm{C}$. Then, the reaction mixture was cooled and evaporated under vacuum. $250 \mathrm{ml}$ of ethyl acetate were added and the organic phase was washed with 2X50 ml water and 1x50 ml brine, dried over $\mathrm{MgSO}_{4}$, filtered, and evaporated under reduced pressure. Yields varied from 50 to $98 \%$.

Procedure for the synthesis of intermediate (5h). $3.25 \mathrm{mmol}$ of Boc-tetramic acid (5-secbutylpyrrolidine-2, 4-dione (BOC)), 2-amino-anisaldehyde obtained as previously reported ${ }^{16-17}$ and $5 \mathrm{ml}$ DMF were added into a microwave reaction vial. The vial was flushed with nitrogen, sealed and irradiated for $30 \mathrm{~min}$ at $80^{\circ} \mathrm{C}$ (reaction completion was verified by HPLC). Water (50 $\mathrm{ml}$ ) was added to the DMF. The mixture was extracted with ethyl acetate $(2 \times 50 \mathrm{ml})$, the organic phases were combined and washed with water $(5 \times 50 \mathrm{ml})$ and brine $(1 \times 50)$, dried over $\mathrm{MgSO}_{4}$, filtered, and evaporated under reduced pressure. Compound $5 \mathrm{~h}$ was desalted using DOWEX 50WX2-100 and then purified by silica gel chromatography (Hexane/EtOAc 2:1) Rf=0.65 (yield $35 \%)$.

\section{General procedure for the synthesis of intermediates (6a-h)}

The methylation reaction was performed according to a previous reported procedure ${ }^{12}$. Briefly, $60 \mathrm{ml}$ dry $\mathrm{CH}_{2} \mathrm{Cl}_{2}$ was added to quinoline $5 \mathrm{a}-\mathrm{h}(1.31 \mathrm{mmol})$ in $100 \mathrm{ml}$ round bottom flask. Then, a large excess of methyl triflate $(1 \mathrm{ml})$ was added to the flask under nitrogen condition. After 48 $\mathrm{h}$ of stirring at room temp., the resulting solid was filtered and washed with $\mathrm{CH}_{2} \mathrm{Cl}_{2}$ to afford quite pure product as a yellow powder. Yields varied from 35 to $82 \%$.

Procedure for the synthesis of (7h). The de-methylation reaction was performed according to a previous reported procedure with minor changes. ${ }^{13}$ Briefly intermediate product $6 \mathrm{~h}(40 \mathrm{mg}$, $0.09 \mathrm{mmol}$ ) was placed in a $25 \mathrm{ml}$ round bottom flask flushed with nitrogen and sealed. The flask was cooled to $0^{\circ} \mathrm{C}$ and boron tribromide ( $1 \mathrm{M}$ in dichloromethane, $10 \mathrm{ml}, 0.01 \mathrm{~mol}$ ) was added and the reaction mixture was allowed to stir at room temperature for 7 days (reaction was monitored by HPLC to completion). The excess boron tribromide was then neutralized by the addition of methanol $(30 \mathrm{ml})$ and stirring for another $30 \mathrm{~min}$. The mixture was concentrated under reduced pressure. Product mixture was purified by preparative HPLC method (see general methods). After lyophilization $12 \mathrm{mg}$ of pure diastereomeric mixture were obtained (yield $40 \%$ ). See physical properties below. 
Physical properties of compounds 6a. ${ }^{1} \mathrm{H}$ NMR: (300 M Hz, DMSO- $\left.d_{6}\right), \delta \mathrm{H}$ (ppm): 4.49 (s, $3 \mathrm{H}), 5.04(\mathrm{~s}, 2 \mathrm{H}), 8.13(\mathrm{t}, 1 \mathrm{H}, J=7.5 \mathrm{~Hz}), 8.4(\mathrm{t}, 1 \mathrm{H}, J=7.9 \mathrm{~Hz}), 8.65(\mathrm{~d}, 1 \mathrm{H}, J=2.7 \mathrm{~Hz}), 8.67$ $(\mathrm{d}, 1 \mathrm{H}, J=3 \mathrm{~Hz}) .{ }^{13} \mathrm{C}$ NMR: (75 M Hz, DMSO- $d_{6}, \delta \mathrm{C}(\mathrm{ppm}): 39.76,45.83,118.74,126.76$, 128.68, 129.84, 132.22, 136.91, 139.39, 141.91, 163.17, 164.89. (Yield 81.6\%) MS: MW = 199 $\mathrm{g} / \mathrm{mol}, \mathrm{MH}^{+}=199$. HRMS calc. for $\mathrm{C}_{12} \mathrm{H}_{11} \mathrm{~N}_{2} \mathrm{O}$ : 199.087, found: 199.088 HPLC: $\mathrm{tr}=1.578 \mathrm{~min}$.

6b (Major SS, obtained as mixture with minor RS). ${ }^{1} \mathrm{H}$ NMR: (700 M Hz, DMSO- $d_{6}, \delta \mathrm{H}$ (ppm): 0.39 (d, 3H, $J=6.3 \mathrm{~Hz}), 1.06(\mathrm{t}, 3 \mathrm{H}, J=7 \mathrm{~Hz}), 1.47(\mathrm{~m}, 1 \mathrm{H}), 1.74(\mathrm{~m}, 1 \mathrm{H}), 2.46(\mathrm{~m}, 1 \mathrm{H})$, $4.62(\mathrm{~s}, 3 \mathrm{H}), 5.49(\mathrm{~d}, 1 \mathrm{H}, J=2.1 \mathrm{~Hz}), 8.15(\mathrm{t}, 1 \mathrm{H}, J=7.35), 8.42(\mathrm{t}, 1 \mathrm{H}, J=8.4 \mathrm{~Hz}), 8.66(\mathrm{~m}$, 1H), 8.67 (m, 1H), 9.65 (s, 1H), 9.73 (bs, 1H, NH). ${ }^{13} \mathrm{C}$ NMR: (175 M Hz, DMSO- $d_{6}, \delta \mathrm{C}(\mathrm{ppm})$ : 11.85, 11.97, 27.39, 36.07, 40.0, 60.07, 119.44, 126.93, 128.86, 130.05, 132.17, 137.02, 140.25, 142.08, 164.39, 164.66. (Yield 18\%) $\mathrm{MS}: \mathrm{MW}=255 \mathrm{~g} / \mathrm{mol}, \mathrm{MH}^{+}=255$. HRMS calc. for $\mathrm{C}_{16} \mathrm{H}_{19} \mathrm{~N}_{2} \mathrm{O}: 255.149$, found: 255.149. HPLC: $\operatorname{tr}=3.243 \mathrm{~min}$.

6b (Minor $\boldsymbol{R S}$ ). ${ }^{1} \mathrm{H}$ NMR: (700 M Hz, DMSO-d6), $\delta \mathrm{H}(\mathrm{ppm}): 0.59$ (m, 1H), 0.64 (t, 3H, $J=7.7$ $\mathrm{Hz}), 0.87(\mathrm{~m}, 1 \mathrm{H}), 1.25(\mathrm{~d}, 3 \mathrm{H}, J=7 \mathrm{~Hz}), 2.44(\mathrm{~m}, 1 \mathrm{H}), 4.64(\mathrm{~s}, 3 \mathrm{H}), 5.44(\mathrm{~d}, 1 \mathrm{H}, J=1.4 \mathrm{~Hz})$, $8.15(\mathrm{t}, 1 \mathrm{H}, J=7.35), 8.42(\mathrm{t}, 1 \mathrm{H}, J=8.4 \mathrm{~Hz}), 8.66(\mathrm{~m}, 1 \mathrm{H}), 8.67(\mathrm{~m}, 1 \mathrm{H}), 9.63(\mathrm{~s}, 1 \mathrm{H}), 9.8$ (bs,1H,NH). ${ }^{13} \mathrm{C}$ NMR: (175 M Hz, DMSO- $d_{6}, \delta \mathrm{C}(\mathrm{ppm}): 11.26,17.08,21.47,36.17,40.7$, 61.78, 119.46, 127.08, 128.86, 130.05, 132.15, 136.96, 140.24, 141.87, 164.21, 164.49. (Yield 17\%) MS: $\mathrm{MW}=255 \mathrm{~g} / \mathrm{mol}, \mathrm{MH}^{+}=255$. HRMS calc. for $\mathrm{C}_{16} \mathrm{H}_{19} \mathrm{~N}_{2} \mathrm{O}: 255.149$, found: 255.149 . HPLC: $\operatorname{tr}=3.243 \mathrm{~min}$.

6c. ${ }^{1} \mathrm{H}$ NMR: (700 M Hz, DMSO- $\left.d_{6}\right), \delta \mathrm{H}(\mathrm{ppm}): 0.4(\mathrm{~d}, 3 \mathrm{H}, J=6.6 \mathrm{~Hz}), 1.25(\mathrm{~d}, 3 \mathrm{H}, J=6.9$ $\mathrm{Hz}), 2.74(\mathrm{~m}, 1 \mathrm{H}), 4.64(\mathrm{~s}, 3 \mathrm{H}), 5.43(\mathrm{~s}, 1 \mathrm{H}), 8.14(\mathrm{t}, 1 \mathrm{H}, J=7.8 \mathrm{~Hz}), 8.41(\mathrm{t}, 1 \mathrm{H}, J=6.2 \mathrm{~Hz})$, $8.65(\mathrm{~s}, 1 \mathrm{H}),, 8.66(\mathrm{~s}, 1 \mathrm{H}), 9.63(\mathrm{~s} .1 \mathrm{H}), 9.77(\mathrm{NH}, \mathrm{s}) .{ }^{13} \mathrm{C}$ NMR: $\left(175 \mathrm{M} \mathrm{Hz}, \mathrm{DMSO}-d_{6}, \delta \mathrm{C}(\mathrm{ppm})\right.$ : 14.39, 20.66, 29.66, 40.73, 61.34, 119.45, 126.86, 128.90, 130.04, 137.07,132.18, 140.28, 142.08, 164.28, 167.74. (Yield 57.3\%) $\mathrm{MS}: \mathrm{MW}=241 \mathrm{~g} / \mathrm{mol}, \mathrm{MH}^{+}=241$. HRMS calc. for $\mathrm{C}_{15} \mathrm{H}_{17} \mathrm{~N}_{2} \mathrm{O}: 241.134$, found: 241.133. HPLC: $\operatorname{tr}=3.037 \mathrm{~min}$.

6d. ${ }^{1} \mathrm{H}$ NMR: (300 M Hz, DMSO-d6), $\delta \mathrm{H}(\mathrm{ppm}): 3.3(\mathrm{~m}, 2 \mathrm{H}), 4.81(\mathrm{~s}, 3 \mathrm{H}), 5.85(\mathrm{t}, 1 \mathrm{H}, J=4.2$ $\mathrm{Hz}), 7.07(\mathrm{~m}, 5 \mathrm{H}), 8.14(\mathrm{t}, 1 \mathrm{H}, J=7.8 \mathrm{~Hz}), 8.41(\mathrm{t}, 1 \mathrm{H}, J=6.2 \mathrm{~Hz}), 8.53(\mathrm{~d}, 1 \mathrm{H}, J=8.1 \mathrm{~Hz})$, $8.70\left((\mathrm{~d}, 1 \mathrm{H}, J=9 \mathrm{~Hz}), 9.36(\mathrm{~s}, 1 \mathrm{H}), 9.77(\mathrm{~s}, 1 \mathrm{H}, \mathrm{NH},) .{ }^{13} \mathrm{C}\right.$ NMR: $\left(75 \mathrm{M} \mathrm{Hz}, \mathrm{DMSO}-d_{6}\right), \delta \mathrm{C}$ (ppm): 37.06, 40.89, 57.19, 119.32, 126.89, 127.24, 128.18, 128.63,129.56, 130.29, 132.15, 133.75, 137.3, 139.65, 141.74, 163.65, 164.08. (Yield 66.4\%) MS: MW = 241 g/mol, $\mathrm{MH}^{+}=241$. HRMS calc. for $\mathrm{C}_{19} \mathrm{H}_{17} \mathrm{~N}_{2} \mathrm{O}: 289.133$, found: 289.132 . HPLC: $\operatorname{tr}=3.278 \mathrm{~min}$.

6e. ${ }^{1} \mathrm{H}$ NMR: (300 M Hz, DMSO- $d_{6}$ ), $\delta \mathrm{H}(\mathrm{ppm}): 1.64$ (d, 3H), 4.57 (s, 3H), 5.48 (q, 1H, $J=6.6$ $\mathrm{Hz}), 8.14(\mathrm{t}, 1 \mathrm{H}, J=10.5 \mathrm{~Hz}), 8.41(\mathrm{t}, 1 \mathrm{H}, J=8.85 \mathrm{~Hz}), 8.64(\mathrm{~m}, 1 \mathrm{H}), 8.67(\mathrm{~m}, 1 \mathrm{H}), 9.59$ (s, 1H), 9.63 (s, 1H), ${ }^{13} \mathrm{C} \mathrm{NMR:} \mathrm{(75} \mathrm{M} \mathrm{Hz,} \mathrm{DMSO-d6),} \delta \mathrm{C}$ (ppm ):18.27, 40.46, 52.61, 119.09, 126.55, 128.92, 129.95, 132.09, 136.92, 139.91, 142.36, 163.42, 165.58. (Yield 54.2\%) MS: $\mathrm{MW}=212 \mathrm{~g} / \mathrm{mol}, \mathrm{MH}^{+}=213$. HRMS calc. for $\mathrm{C}_{13} \mathrm{H}_{13} \mathrm{~N}_{2} \mathrm{O}: 213.10$, found: 213.102, HPLC: $\operatorname{tr}=$ $2.579 \mathrm{~min}$.

6f. ${ }^{1} \mathrm{H}$ NMR: (300 M Hz, DMSO- $\left.d_{6}\right), \delta \mathrm{H}(\mathrm{ppm}): 0.87(\mathrm{~d}, 3 \mathrm{H}, J=6.6 \mathrm{~Hz}), 1.08(\mathrm{~d}, 3 \mathrm{H}, J=6.3$ $\mathrm{Hz}), 1.57(\mathrm{~m}, 1 \mathrm{H}), 1.91(\mathrm{~m}, 1 \mathrm{H}), 2.05(\mathrm{~m}, 1 \mathrm{H}), 4.56(\mathrm{~s}, 3 \mathrm{H}), 5.44(\mathrm{~d}, 1 \mathrm{H}, J=8.1 \mathrm{~Hz}), 8.14(\mathrm{t}$, $1 \mathrm{H}, J=7.8), 8.41(\mathrm{t}, 1 \mathrm{H}, J=8.1 \mathrm{~Hz}), 8.64(\mathrm{~s}, 1 \mathrm{H}), 8.67(\mathrm{~s}, 1 \mathrm{H}), 9.64(\mathrm{~s}, 1 \mathrm{H}), 9.88(\mathrm{bs}, 1 \mathrm{H}, \mathrm{NH})$. 
${ }^{13} \mathrm{C}$ NMR: (75 M Hz, DMSO- $d_{6}, \delta \mathrm{C}(\mathrm{ppm}): 21.06,23.44,24.92,40.61,41.09,55.36,119.19$, 126.53, 128.88, 130.01, 132.14, 137.03, 140.02, 142.44, 163.92, 165.11. (Yield 51\%) MS: MW $=255 \mathrm{~g} / \mathrm{mol}, \mathrm{MH}^{+}=255$. HRMS calc. for $\mathrm{C}_{16} \mathrm{H}_{19} \mathrm{~N}_{2} \mathrm{O}: 255.149$, found: 255.150. HPLC: $\operatorname{tr}=$ $3.208 \mathrm{~min}$.

6g. ${ }^{1} \mathrm{H}$ NMR: (300 M Hz, DMSO-d6), $\delta \mathrm{H}(\mathrm{ppm}): 3.31$ (dd, $\left.1 \mathrm{H}, J=3.6 \mathrm{~Hz}, J=18.9 \mathrm{~Hz}\right), 3.52$ (dd, $1 \mathrm{H}, J=5.4 \mathrm{~Hz}, J=17.4 \mathrm{~Hz}), 4.59$ (s, 3H), 4.92 (d, 1H, $J=12.3$ ), 4.95 (d, 1H, $J=12.3$ ), $5.72(\mathrm{t}, 1 \mathrm{H}, J=4.2 \mathrm{~Hz}), 7.2(\mathrm{~m}, 5 \mathrm{H}), 8.13(\mathrm{t}, 1 \mathrm{H}, J=7.5 \mathrm{~Hz}), 8.39(\mathrm{t}, 1 \mathrm{H}, J=6.75 \mathrm{~Hz}), 8.59$ (d, $1 \mathrm{H}, J=8.59 \mathrm{~Hz}), 8.64(\mathrm{~d}, 1 \mathrm{H}, J=9 \mathrm{~Hz}), 9.5(\mathrm{~s}, 1 \mathrm{H}), 9.66(\mathrm{bs}, 1 \mathrm{H}, \mathrm{NH}) .{ }^{13} \mathrm{C} \mathrm{NMR}:(75 \mathrm{M} \mathrm{Hz}$, DMSO-d6), $\delta \mathrm{C}(\mathrm{ppm}): 36.47,40.54,53.43,66.43,118.96,127.34,128.08,128.23,128.31$, 128.69, 130.1, 132.24, 134.96, 137.4, 139.45, 141.46, 163.82, 164.35, 168.72. (Yield 39\%) MS: $\mathrm{MW}=347 \mathrm{~g} / \mathrm{mol}, \mathrm{MH}^{+}=347 . \mathrm{HRMS}$ calc. for $\mathrm{C}_{21} \mathrm{H}_{19} \mathrm{~N}_{2} \mathrm{O}_{3}: 347.139$, found: 347.139 . HPLC: $\operatorname{tr}$ $=3.402 \mathrm{~min}$

6h (Major SS, obtained as mixture with minor RS). ${ }^{1} \mathrm{H}$ NMR: (300 M Hz, DMSO- $d_{6}$ ), $\delta \mathrm{H}(\mathrm{ppm}): 0.56(\mathrm{~m}, 1 \mathrm{H}), 0.62(\mathrm{t}, 3 \mathrm{H}, J=5.1 \mathrm{~Hz}), 0.84(\mathrm{~m}, 1 \mathrm{H}), 1.23(\mathrm{~d}, 3 \mathrm{H}, J=6.9 \mathrm{~Hz}), 2.45(\mathrm{~m}$, $1 \mathrm{H}), 4.17(\mathrm{~s}, 3 \mathrm{H}), 4.54(\mathrm{~s}, 3 \mathrm{H}), 5.4(\mathrm{~s}, 1 \mathrm{H}), 7.76(\mathrm{~m}, 1 \mathrm{H}), 7.79(\mathrm{~m}, 1 \mathrm{H}), 8.54(\mathrm{dd}, 1 \mathrm{H}, J=9 \mathrm{~Hz}$, $J=1.5 \mathrm{~Hz}), 9.43$ (s, 1H), 9.59 (bs, 1H). ${ }^{13} \mathrm{C} \mathrm{NMR:}\left(75 \mathrm{M} \mathrm{Hz}, \mathrm{DMSO}-d_{6}\right), \delta \mathrm{C}(\mathrm{ppm}): 12.28$, 17.64, 21.47, 27.83, 36.39, 57.69, 60.31, 62.05, 100.27, 122.37, 124.89, 134.36, 141.16, 143.58, 163.93, 165.57, 163.74. (Yield 60\%) $\mathrm{MS}: \mathrm{MW}=285 \mathrm{~g} / \mathrm{mol}, \mathrm{MH}^{+}=285$. HRMS calc. for $\mathrm{C}_{17} \mathrm{H}_{21} \mathrm{~N}_{2} \mathrm{O}_{2}$ : 285.160, found: 285.150 HPLC: $\operatorname{tr}=3.42 \mathrm{~min}$.

6h (Minor RS). ${ }^{1} \mathrm{H}$ NMR: (300 M Hz, DMSO- $\left.d_{6}\right), \delta \mathrm{H}(\mathrm{ppm}): 0.36(\mathrm{~d}, 3 \mathrm{H}, J=6.9 \mathrm{~Hz}), 1.05$ (t, $3 \mathrm{H}, J=7.2 \mathrm{~Hz}), 1.48(\mathrm{~m}, 1 \mathrm{H}), 1.7(\mathrm{~m}, 1 \mathrm{H}), 2.45(\mathrm{~m}, 1 \mathrm{H}), 4.17(\mathrm{~s}, 3 \mathrm{H}), 4.51(\mathrm{~s}, 3 \mathrm{H}), 5.37(\mathrm{~s}, 1 \mathrm{H})$, $7.76(\mathrm{~m}, 1 \mathrm{H}), 7.79(\mathrm{~m}, 1 \mathrm{H}), 8.54(\mathrm{dd}, 1 \mathrm{H}, J=9 \mathrm{~Hz}, J=1.5 \mathrm{~Hz}), 9.44(\mathrm{~s}, 1 \mathrm{H}), 9.52(\mathrm{bs}, 1 \mathrm{H}) .{ }^{13} \mathrm{C}$ NMR: (75 M Hz, DMSO- $d_{6}$ ), $\delta \mathrm{C}$ (ppm): 11.72, 17.64, 21.47, 27.83, 36.52, 57.69, 60.31, 62.05, $100.27,122.37,124.89,134.36,140.99,143.58,163.93,165.57,166.74$. (Yield 12\%) MS: MW $=285 \mathrm{~g} / \mathrm{mol}, \mathrm{MH}^{+}=285$. HRMS calc. for $\mathrm{C}_{17} \mathrm{H}_{21} \mathrm{~N}_{2} \mathrm{O}_{2}: 285.160$, found: 285.150 HPLC: $\operatorname{tr}=3.42$ $\min$.

7h (Major SS, obtained as mixture with minor RS). ${ }^{1} \mathrm{HNMR}$ : (700 M Hz, DMSO- $\left.d_{6}\right), \delta \mathrm{H}$ (ppm): $0.59(\mathrm{~m}, 1 \mathrm{H}), 0.62(\mathrm{t}, 3 \mathrm{H}, J=7 \mathrm{~Hz}), 0.85(\mathrm{~m}, 1 \mathrm{H}), 1.22(\mathrm{~d}, 3 \mathrm{H}, J=7 \mathrm{~Hz}), 2.40(\mathrm{~m}, 1 \mathrm{H})$, $4.4(\mathrm{~s}, 3 \mathrm{H}), 5.33(\mathrm{~s}, 1 \mathrm{H}), 7.61(\mathrm{dd}, 1 \mathrm{H}, J=9.1 \mathrm{~Hz}, J=2.1 \mathrm{~Hz}), 7.64(\mathrm{~s}, 1 \mathrm{H}), 8.47(\mathrm{~d}, 1 \mathrm{H}, J=9.1$ $\mathrm{Hz}), 9.33$ (s, 1H), 9.50 (s, NH). ${ }^{13} \mathrm{C}$ NMR: (175 M Hz, DMSO-d6), $\delta \mathrm{C}$ (ppm): 11.14, 17.09, 21.24, 35.99, 39.91, 61.32, 101.74, 121.14, 123.10, 123.42, 134.43, 140.15, 143.20, 163.21, 165.07, 166.22. ${ }^{1} \mathrm{H}$ NMR: (700 M Hz, pyridine- $\left.d_{5}\right), \delta \mathrm{H}(\mathrm{ppm}): 0.52(\mathrm{~d}, 3 \mathrm{H}, J=7 \mathrm{~Hz}), 1.10(\mathrm{t}$, $3 \mathrm{H}, J=7.7 \mathrm{~Hz}), 1.62(\mathrm{~m}, 1 \mathrm{H}), 1.83(\mathrm{~m}, 1 \mathrm{H}), 2.45(\mathrm{~m}, 1 \mathrm{H}), 4.29(\mathrm{~s}, 3 \mathrm{H}), 5.43(\mathrm{~d}, 1 \mathrm{H}, J=2.1$ $\mathrm{Hz}), 7.56(\mathrm{dd}, 1 \mathrm{H}, J=9 \mathrm{~Hz}, J=2.1 \mathrm{~Hz}), 7.99(\mathrm{~d}, 1 \mathrm{H}, J=9 \mathrm{~Hz}), 8.01(\mathrm{~s}, 1 \mathrm{H}), 8.94(\mathrm{~s}, 1 \mathrm{H}), 10.37$ (s, NH). ${ }^{13} \mathrm{C}$ NMR: (175 M Hz, pyridine-d5), $\delta \mathrm{C}$ (ppm): 12.11, 12.20, 28.52, 37.15, 39.17, 59.90, $102.79,120.18,123.00,127.25,133.92,137.57,144.99,161.90,167.19,174.78$. (Yield 30.4\%) MS: $\mathrm{MW}=271 \mathrm{~g} / \mathrm{mol}, \mathrm{MH}^{+}=271$. HRMS calc. for $\mathrm{C}_{16} \mathrm{H}_{19} \mathrm{~N}_{2} \mathrm{O}_{2}: 271.1441$, found: 271.143 HPLC: $\operatorname{tr}=3.08 \mathrm{~min}$.

7h (Minor RS). ${ }^{1} \mathrm{H}$ NMR: (700 M Hz, DMSO- $\left.d_{6}\right), \delta \mathrm{H}(\mathrm{ppm}): 0.37(\mathrm{~d}, 3 \mathrm{H}, J=6.3 \mathrm{~Hz}), 1.03$ (t, $3 \mathrm{H}, J=7 \mathrm{~Hz}), 1.45(\mathrm{~m}, 1 \mathrm{H}), 1.70(\mathrm{~m}, 1 \mathrm{H}), 2.40(\mathrm{~m}, 1 \mathrm{H}), 4.38(\mathrm{~s}, 3 \mathrm{H}), 5.39$ (s, 1H), $7.61(\mathrm{dd}, 1 \mathrm{H}$, 
$J=9.1 \mathrm{~Hz}, J=2.1 \mathrm{~Hz}), 7.64(\mathrm{~s}, 1 \mathrm{H}), 8.47(\mathrm{~d}, 1 \mathrm{H}, J=9.1 \mathrm{~Hz}), 9.34(\mathrm{~s}, 1 \mathrm{H}), 9.43(\mathrm{~s}, \mathrm{NH}) .{ }^{13} \mathrm{C}$ NMR: $\left(175 \mathrm{M} \mathrm{Hz}, \mathrm{DMSO}-d_{6}, \delta \mathrm{C}\right.$ (ppm): 11.74, 11.75, 27.25, 35.88, 39.85, 59.53, 101.71, 121.14, 122.95, 123.42, 134.45, 140.29, 143.22, 163.42, 165.24, 166.22. ${ }^{1} \mathrm{H}$ NMR: (700 M Hz, pyridine- $\left.d_{5}\right), \delta \mathrm{H}(\mathrm{ppm}): 0.61(\mathrm{t}, 3 \mathrm{H}, J=7.7 \mathrm{~Hz}), 0.81(\mathrm{~m}, 1 \mathrm{H}), 1.05(\mathrm{~m}, 1 \mathrm{H}), 1.37(\mathrm{~d}, 3 \mathrm{H}, J=7$ $\mathrm{Hz}), 2.50(\mathrm{~m}, 1 \mathrm{H}), 4.31(\mathrm{~s}, 3 \mathrm{H}), 5.40(\mathrm{~d}, 1 \mathrm{H}, J=2.1 \mathrm{~Hz}), 7.57(\mathrm{dd}, 1 \mathrm{H}, J=9.1 \mathrm{~Hz}, J=2.1 \mathrm{~Hz})$, $7.97(\mathrm{~s}, 1 \mathrm{H}), 8.00(\mathrm{~d}, 1 \mathrm{H}, J=9 \mathrm{~Hz}), 8.95(\mathrm{~s}, 1 \mathrm{H}), 10.47$ (s, NH). ${ }^{13} \mathrm{CNMR}$ : $(175 \mathrm{M} \mathrm{Hz}$, pyridine$d_{5}, \delta \mathrm{C}(\mathrm{ppm}): 11.55,17.94,22.04,37.15,39.22,62.08,102.79,120.32,123.00,127.25,133.88$, 137.51, 144.93, 161.58, 167.01, 174.72. (Yield 9.6\%) MS: $\mathrm{MW}=271 \mathrm{~g} / \mathrm{mol}, \mathrm{MH}^{+}=271$. HRMS calc. for $\mathrm{C}_{16} \mathrm{H}_{19} \mathrm{~N}_{2} \mathrm{O}_{2}$ : 271.1441, found: $271.143 \mathrm{HPLC}: \operatorname{tr}=3.08 \mathrm{~min}$.

\section{Acknowledgements}

This work was financed by an internal found of Bar Ilan University. We are indebted to the "Marcus Centre for Medicinal Chemistry" for supporting equipment acquisition. We thank Dr Rachel Persky from the Structural Analysis Department of Bar-Ilan University for MS analysis of products and to Dr. Shai Rahimipour and Mgr.Tal Shalev for XTT and MIC biological assays.

\section{References and Notes}

1. Kozlovsky, A. G.; Zhelifonova, V. P.; Antipova, T. V.; Adanin, V. M.; Ozerskaya, S. M.; Kochkina, G.A.;Schlegel, B.; Dahse, H. M.; Gollmick, F. A.; Grafe, U. J. Antibiot. 2003, 56, 488.

2. Arinbasarova, A. Yu.; Medentsev, A. G.; Kozlovsky, A. G. Appl. Biochem. Microbiol. 2007, 43, 625 .

3. Pozmogova, I. I. Microbiologiia 1971, 40, 1046.

4. Terada, H. Biochem. Biophys. Acta 1980, 639, 225.

5. MacLaghlin, S. G. A.; Dilger, J. P. Physiol. Rev. 1980, 60, 825.

6. Kawai, K.; Nozawa, Y.; Maebayashi, Y.; Yamazaki, M.; Hamasaki, T. Appl. Environ. Microbiol. 1984, 47, 481.

7. Kawai, K.; Nakamura, T.; Nozawa, Y. Proc. Japan. Assoc. Micotoxicol. 1982, 15, 19.

8. Akimenko, V. K.; Kozlovskii, A.G.; Medentsev, A.G.; Golovchenko, N.P.; Arinbasarov, M.U. Biokhimiya 1976, 41, 2220.

9. Ito, Y.; Kawai, K.; Nozawa, Y. J. Biochem. 1973, 74, 805.

10. Malecki, N.; Carato, P.; Rigo, B.; Goossens, J.F.; Houssin, R.; Bailly C.; Henichart, J. P. Bioorg. Med. Chem. 2004, 12, 641.

11. Byk, G.; Kabha, E. J. Comb. Chem. 2004, 6, 596.

12. Labruère, R.; Helissey, P.; Desbène-Finck, S.; Giorgi-Renault, S. J. Org. Chem. 2008, 73, 3642 . 
13. Piyamongkol, S.; Liu, Z. D.; Hider R. C. Tetrahedron 2001, 57, 3479.

14. Takahashi, S.; Kakinuma, N.; Iwai, H.; Yaganisawa, T.; Nagai, K.; Suzuki, K.; Tokunaga, T.; Nakagawa, A. J. Antibiot. 2000, 53, 1252.

15. Clinical and Laboratory Standards Institute. Methods for Determining Bactericidal Activity of Antimicrobial Agents: Approved Guideline M26-A. CLSI, Wayne, PA, USA, 1999: http://www.clsi.org/source/orders/free/m26-a.pdf.

16. A.I. Vogel in A Text-Book of Practical Organic Chemistry, Including Qualitative Organic Analysis, A.I. Vogel, $3^{\text {rd }}$ ed.; Longmans, Green and Co.: London, 1956; pp 331-332.

17. Woodward, R. B.; Bader, F. E.; Bickel, H.; Frey, A. J.; Kierstead, R. W. Tetrahedron 1958, 2,1 . 